\title{
The growth of partnership in mission in global mission history during the twentieth century
}

\author{
Graham A Duncan \\ Department of Church History and Church Polity \\ University of Pretoria
}

\begin{abstract}
Partnership in mission came to be a byword for developing missionary relationships during the twentieth century. During this time its meaning and practice changed, often imperceptibly. This is seen in the regular conferences of the International Missionary Conference and its successors which had their origin in the International Missionary Conference held in Edinburgh, 1910. A further problem was making the concept a reality in relationships despite great disparities in resources. This has given rise to the negative critique of the slogan as empty and meaningless.
\end{abstract}

Partnership - “... the ecumenical movement's guiding principle of sharing of resources" (Wisniewski 2006:7). "We need one another to be effective instruments of God in multi-lateral mission today" (Nyomi 2006:14).

\section{INTRODUCTION}

During the twentieth century the concept of partnership in mission came to dominate as a description of the nature of relationships between older and younger churches throughout the world. Verkuyl (1978:311) asserts that the origin of partnership lies in the rejection by indigenous churches of the status of children. Yet, Newbigin (1958:27) claimed that in mission "the homebase is everywhere". This kind of thinking undermined paternalistic "dominator" structures and attitudes which controlled missions for too long and promoted the concept of mutuality in mission. In this article, we shall consider the International Missionary Conferences (IMC), its successors and, where relevant, other related conferences and issues. 


\section{CONFERENCES}

\subsection{Edinburgh, 1910}

Although there had been instances of missionary co-operation as in India from 1885 through the drawing of comity agreements in which "peaceful coexistence without mutual aggression and rivalry had come to be accepted as the norm" (Neill 1976:4), the World Missionary Conference, 1910, marked the first occasion that missionary societies began to work together. It was the culmination of a century's attempts to co-operate and signified the beginning of the ecumenical movement and the coalescence of mission and unity in "mission ecumenism" (Bauerochse 2001:4). It therefore represented a particular kairos (Bosch 1980:160). The main interest of the conference was the unity of the church in its relationship to the world. The conference prepared the way for the formation of the International Missionary Council and the WCC, and the Faith and Order Movement focussing on doctrinal matters (which Edinburgh deliberately eschewed), and the Life and Work Movement focussing on social, economic and political life. There were very few representatives from the churches which were derived from the modern missionary movement, but those who were present were clear that there needed to be changes in relationships between the "older" and "younger" churches. Two major tasks emerged from the conference; the need for mission societies to work in closer relationship and the equal if not greater need for the development of relationships with local churches. V S Azariah, a delegate from India affirmed: "You have given your goods to feed the poor. You have given your bodies to be burned. We ask for love. Give us friends" (i e relationships) (Brown 1997:210). This was written in the context of certain aloofness, a lack of mutual understanding and openness, a great lack of frank intercourse and friendliness ..." (in Bauerochse 2001:8). This is not at all surprising when nations were designated respectively as the "more backward races of mankind" and the "more advanced" (World Missionary Conference 1910, in Botha 2005:132). Friendship might therefore be defined as "working together as equals, living together at a considerate human level, celebrating together and learning from each other" (Bauerochse 2001:19).

In sum, S Neill (GA 1960:442) commented: "It was indeed the beginning of an epoch - the epoch of reflection and of ecumenical cooperation; and at the same time it was the end of an epoch - the epoch of glad and confident expansion of the Christian missionary enterprise, under the inspiration of a rediscovery of the Gospel." The Edinburgh meeting "anticipated, though it did not fully realize, the concept of "partnership in 
obedience' of churches in all six continents in continuing and completing the unfinished task" (Scherer 1987:19).

\subsection{Lake Mohonk, IMC, 1921}

It was at this venue in New York that the IMC was formed. Here, questions were raised concerning the relationship of missionaries to indigenous workers, their respective roles in decision-making, consultation regarding missionary appointments, the relation of donor funds to self-support and their control and mutual co-operation in the training of missionaries and local workers. However, a new epoch was dawning on the world scene as the rise of nationalism became a turning point in world history. This was attested in two papers presented and the Faith and Order conference held in Lausanne in 1927. Significant here were early calls for the unity of the church. Disunity caused many problems for young churches and fuelled the nationalist call as for example in India:

The rising tide of nationalism cannot be ignored. The new national spirit calls for national unity. The young Indian Christian cannot help being influenced by this new spirit. His patriotism moves him to do what he can to advance the interests of his own country, while his loyalty to Christ makes him long for his country to come into the full inheritance of eternal life in Jesus Christ. This national and Christian consciousness in consequence unites him with his fellow Christians of all Churches in the common task of the material and spiritual regeneration of his country in and through Christ.

(Dornakal, in Bate [ed] 1927:493)

This same sense was evident also in China: "There is rising in China the allpowerful nationalism which challenges Christianity" (Lew 1927:497). These challenges arose, in part from the disunity of the Christian faith: "Christianity is being looked upon with grave suspicion at this moment in China because, while it professes to teach love and unity, it is divided against itself" (Lew 1927:497). It became clear that there was considerable dissatisfaction with the dissonance between expressions of unity and the continuing disunity of the body of Christ worldwide. Disunity was a source of the church's weakness and there was resistance to perpetuating this: "force of habit, financial dependence, denominational training and, above all, loyalty to their spiritual fathers, now keep them in denominational connections. But these circumstances cannot keep them apart forever" (Dornakal 1927:493) 
Yet, the nationalist agenda influenced the conceptualization of this united church:

We want a Church of India, a Church which can be our spiritual home, a Church where the Indian religious genius can find natural expression, a living branch of the Holy, Catholic and Apostolic Church, a Church which, being a visible symbol of unity in that divided land, will draw all men to our blessed Lord. ... The young churches are waiting for a lead.

(Dornakal 1927:495)

So there was a desire to replace denominationalism with nationalism as a defining factor though it would become apparent that ridding itself of the denominational aspect was less simple than was assumed.

\subsection{Jerusalem, IMC, 1928}

This meeting of the IMC was significant for the relationship between older and younger churches. Much had changed since Edinburgh 1910, not least the political, cultural, religious, social and racial shape of the post-World War I world. However, it began on a sour note as the Nordic Missionary Council had objected to the invitation of "additional" representatives with full voting rights. It may be significant that these representatives were all from younger churches and had the potential to outvote the existing members. It was agreed with $\mathrm{J} \mathrm{H}$ Oldham (conference secretary) that it was more important to secure the cooperation of the new members than to enforce constitutional regulations. This was the price of the now obvious visibility of the younger churches.

The conference was far smaller in terms of numbers, yet, the representation of the younger churches was one third of the total, much larger and more significant than on 1910. At Jerusalem, John Mott (IMC conference chair) called for ending the distinction between sending and receiving churches (Bosch 1991:465) and their admission as churches with "full parity" because it was recognized that they: "had achieved a degree of Christian maturity self-authoritative in its unsponsored claim for equality. Their representatives proved beyond all question that in insight, initiative, and ability to assume responsibility through comprehensive planning, they has come into their own" (in Bauerochse 2001:12).

This, of course, produced a degree of tension, but at least now the questions were tabled frankly, even if they were not addressed in any depth at this juncture. Another issue that caused tension was that of financial independence when it came to defining what constituted an indigenous 
church. The three self formula was found to be wanting. Even the early Church in Jerusalem was not financially independent. And, further, within the Reforming tradition, financial independence does not constitute a mark of the church. For Mott, the critical issue was: "If a church is truly indigenous, the church edifice is planted right in the heart of the people, wherever they are" (in Bauerochse 2001:14). While some western delegates were suspicious of progressing too quickly, they raised issues of the fear of syncretism and the need to avoid the violation of missionaries" consciences through too speedy indigenization. However, the demand from a shift in thinking and action was strong:

The hour has come for passing from paternalism to partnership. It is something more than even cooperation; it is partnership that is required. We want the fullest spiritual fellowship with what we call the younger churches .... We must go on in a fellowship in which there is confidence. ... We have been thinking of ourselves as benefactors. Now we think of ourselves as brethren. Soon we shall be thinking of ourselves as beneficiaries. We speak about sending deputations to the field; let us invite the young churches to come and tell us at home about their spiritual life.

(Dr J H Franklin American Baptist Mission, in Bauerochse 2001:15, 16)

These were prophetic words indeed and we still struggle with such impulses as did many delegates at Jerusalem! Notable here was the conceptual shift from paternalism to fraternalism.

The conference produced a document on the relation between older and younger churches which focused on partnership and noted that the call to mission was the responsibility of all Christians, yet that each church needed to form expressions of its faith within its own particular context in terms of proclamation, liturgy, rituals, art and building design, and maintain the living heritage of the Church universal while engaging in mission. This will be done in concert with the "older" churches. Mission became the task of indigenous churches rather than mission societies. It is into this context that resources of personnel and finance will be utilized through consultation. And so "The younger churches can serve the older at their home base by giving them a fresh inspiration and new interpretation of the Christian message through deputations" (Bauerochse 2001:17). Such relationships could only develop if the mutual understanding and trust that were implicit were to become determining principles for the relationships. However, a surprising and proleptic proposal was suggested by an Indian church leader, P Oomman Philip: "I sometimes think it would be a good thing for the growth of the 
indigenous churches in India if by some cataclysm, such as happened in China, this flow of men and money from churches of the West may be arrested, even for a short time" (Silcock 1928:178-179).

The significance of this proposal was that it anticipated the discussion on moratorium which would erupt at Bangkok 45 years later. Yet, it becomes clear that the younger churches were not only in relationships for what they could derive from them. This kind of thinking constituted a serious threat to the older churches for if it were to be enforced and they were precluded from engaging in missionary activity, their whole raison d'etre for existing would be undermined since the conference affirmed the central locus of the indigenous church (Jerusalem Meeting Report 1928:33). A further critique of the existing missionary enterprise was the acknowledgment that one of the factors which hampered the progress of God's mission was the disunity which the older churches brought to the exercise. This was:

The desire that is being expressed with increasing emphasis among the younger churches to eliminate the complexity of the missionary enterprise and to remove the discredit to the Christian name, due to the great numbers of denominations and the diversity and even competition of the missionary agencies now at work in some countries.

(Jerusalem Meeting Report 1928:37)

This problem was seen to be a western self-imposed restriction on the missionary enterprise and the imposition of norms that did not accord with the Christian message. This period, 1910-1938, focused on discovering institutionalized means of co-ordinating work and sharing information, first between older churches and then including "emerging church structures in other continents" (Matthey 1999:105).

\subsection{Tambaram, IMC, 1938}

As the century progressed, the optimistic spirit of missions had deteriorated somewhat; earlier confidence in the success of the task had evaporated. The conference, which met for the first time in a mission area and had more delegates from younger than older churches, pursued the topics which had engaged its mind at Jerusalem ten years earlier in particular the consolidating of the younger churches for mission. Yet, in terms of partnership its thinking did not progress beyond what was achieved at Jerusalem although the younger churches were now considered to be learners. A significant theme of 
the conference was the worldwide unity of the body of Christ (cf IMC 1939:155):

young churches and old churches work together in a unity flowing out of a common urge to proclaim the gospel .... Within such a perspective, receiving help, whether in the form of money or of personnel, is not something to be ashamed of. Nor is there room for resentment when the churches who receive it claim the right to decide how to use such assistance to best advantage. The important thing is the proper functioning, not the fortifying of the rights of the donor or the recipient. Such a spirit can only lead to an alliance and a partnership with more mutual understanding and a marshalling of Christian forces on the battle front where the need for militant evangelizing is the most acute.

(Paul Devanandan 1939, The Guardian, in Verkuyl 1978:310)

These sentiments were to be reaffirmed at Mexico City in 1963 in its theme of mission in six continents. However, in the conference report section on "Cooperation and unity" (IMC 1939:151-156), there was an expression of frustration as "eagerness to cooperate among the younger churches is thwarted by a too rigid control from abroad, and we cannot too strongly urge that such rigidity of control must be relaxed if the younger churches are to grow into fullness of Christian life and experience and service" (IMC 1939:153). The antidote was clear: "a pooling of all resources and ... cooperation of all Christians" (IMC 1939:37). A two street of mission was required as the population of Europe was moving inexorably towards secularism: "there is in Europe a concerted, organized attempt to secularise the minds of millions of Christian people" (IMC 1939:34). This issued in an "appeal to the younger churches to help the older churches by sending to them missionaries of witness and fellowship" (IMC 1939:41). This was an early example of mission on reverse for: "The work to be done is so vast, so urgent and so important, that it calls for all the resources of all Christians in all parts of the world. The task in this new day must be undertaken by a partnership between the older and younger churches, by a pooling of all resources and by co-operation of all Christians" (IMC 1939:37).

Bauerochse has described this as "a partnership of convenience in order to complete a task" (2001:23). However, any pooling of resources remained a pipe dream. This kind of thinking is an advance on that of Jerusalem because here mission is located in the local church. While financial assistance continued to be required it was not to be allocated for specific 
purposes to the church budget. While Jerusalem focused on partnership as a relationship of trust and fellowship, at Tambaram it becomes an active term effective co-operation in the "unfinished task of evangelism" as the responsibility of the entire church (Matthey 1999:105).

\subsection{Whitby, IMC, 1947}

"This was the first world missionary conference at which the representatives of world Christianity faced each other as partners" (Menzel \& Muller 1997:339). It was also the first international meeting following the Second World War. While Whitby echoed many of the emphases of the Jerusalem conference, the term "Partnership in Obedience" gained general currency and was conceived as solidarity in common need through koinonia, common service rather than domination. Yet; "It is to be noted that Whitby spoke, not of Partnership, but of Partnership in Obedience; it was not in the least interested in human arrangements, which might be dissoluble at will, but only in a common submission to the will of God such as can result only in a divine and permanent fellowship among men" (Ransom 1948:175).

However, partnership was largely experienced by younger churches as empty and meaningless (Verkuyl 1978:309). "An Indonesian pastor once trenchantly remarked to a Dutch professor "Yes, partnership for you, but obedience for us" (Jansen Schoonhoven 1977:48, in Bosch 1991:466). Walter Freytag (in Bauerochse 2001:27) commented on the attitude of "the young churches, whose young members thought little of commitment to tradition and pressed forward unimpressed by the deliberation taught by years of experience". This brashness can be quite disconcerting for seasoned missionaries, but it can also be quite refreshing to those with an open honest approach to the missionary task. "The [partnership] concept would come under scrutiny in years to come and in some circles it would be criticized as just as hollow and meaningless as other slogans and phrases at giving credence to the relationship between churches in mission" (Botha 2005:143). Part of the reason for the ambivalence towards partnership in mission was its appearance as another brand of colonial domination at a time when younger church nations were struggling towards political independence. They found it both difficult and contradictory to continue to accept western domination in this new emerging context. Further, the distinction between older and younger churches was fast disappearing in face of the common tasks that were faced which required a common witness.

Verkuyl (1978:323; see Scherer 1987:95) lays a great emphasis on partnership in training and use of personnel, finance, and policy formation (administration). Self support and self sufficiency were considered urgent 
priorities. Behind this lay a concern to develop global partnership in evangelism by strengthening the spiritual life, ecumenical awareness, missionary commitment, lay involvement and stewardship: "the grace of receiving and the grace of giving were alike necessary" (Scherer 1987:95). Part, at least, of the motivation for this was the sending churches growing awareness that they could not achieve this mammoth task alone, especially in the face of growing independence movements throughout the mission field. However, in relation to finance there were enormous discrepancies between the stipends paid to missionaries and local workers and this was not considered serious enough to warrant radical action to avoid friction and weaken the relationships. The significance of the evangelical task was the single unifying factor in mission, yet, only parts of it were implemented and there were serious lacunae when its came to looking at remuneration from a Christian point of view. This also affected the process of reaching decisions. Scherer (1987:94-5) commented on this in the light of Christ's missionary command which "cannot be fulfilled unless all the forces of all the churches, older and younger alike, are gathered in a common loyalty, inspired by a common task and mobilized by in a common service". The differences between the younger and older churches were disappearing in a sense. This was the essence of authentic partnership.

The conference issued a declaration at its close which defines partnership as the result of expediency. Apart from the impetus of the Spirit of God driving people towards unity, there was also a significant external threat arising out of the disintegration of the colonial empires and the growing secularization in the West which made partnership necessary. Yet, there were great opportunities for mission too. While the years following the war would be crucial for the future both of the world and mission, there was great potential for the development of the young churches which were emerging from the missionary agencies from the West.

Arising out of the Whitby conference, Stephen Neill offered on a study of the concept of partnership in "The myth of the younger churches" (papers from Whitby). For him, positive developments such as numerical growth and trained ministers and locally developed theology, had to be tempered by a realistic evaluation of their difficulties. It is true that they faced a great task and could not do it alone but that did not prevent them from being the church in their respective areas. We have already noted the need for interdependence. From this emerged the Whitby concept of partnership as having the pragmatic aim of bringing all possible agencies together to achieve the evangelization of the world. This reinforced the position of missionaries as vital links in the chain and gives a strong impression of securing vested interests. 
At a later date Max Warren (1956) also wrote on the subject of partnership but from a theological and ecclesiological perspective. Partnership is "Sharing with one another and others in action" (in Bauerochse 2001:35). So partnership is a dynamic activity based in involvement, responsibility and accountability. Warren also adds freedom as the key, for without freedom of will to choose the partnership cannot function. For Warren, partnership is the opposite of the "ethics of dominating power" (in Bauerochse 2001:35).

Therefore, it involves transformation, vulnerability and risk and is, consequently, a "new creation" (Rv 21:5). Warren's theology of partnership is of the essence of our relationship with God as, for example in humans beings being appointed stewards of God's creation (Gn 2:15): “... partnership is an idea congenial to the very nature of God ..., that partnership speaks of God's relationship with man ..., that partnership indicates the true relationship between man and his fellow-men" (in Bauerochse 2001:36). God's relationship with human beings is marked by redemptive service and love which is encapsulated in koinonia and being "in Christ" (2 Cor 5:17). This is the ground of Christian fellowship which "belongs to the nature of the church and its theologically grounded way of existence" (Bauerochse 2001:37). Since God has entered into a partner relationship in the Trinity, and with human beings, it is vital that human beings relate to one another on similar manner.

In 1948, the World Council of Churches (WCC) was established and this brought to fruition a great desire of the younger churches for a global forum for inter-church relations. A basic impulse in this new creation was the recognition that all churches were engaged in common witness, and, "spoke of the acceptance of all self-governing Churches, in whatever part of the world they existed, as full and equal members of a consultative assembly" (Kirk 1999:185). This precipitated discussions regarding the integration of the WCC and the IMC. This led to both mission and inter-church relations being worked out in an ecumenical spirit.

\subsection{Willingen, IMC, 1952}

This meeting of the IMC took place in an atmosphere of crisis for China had closed its borders to missionaries, the colonial period was fast approaching its demise and the expected post-World War II revival had failed to materialize in the face of a revival of eastern religions and the growth of secularisation. From this point mission is regarded as participation in the missio Dei; this is the work of the partnership in the Trinity in partnership in mission with churches. And, the natural progression ought to have been the integration of mission and church: "We should cease to speak of missions and churches and avoid this dichotomy not only in our thinking but also in our actions. We 
should now speak about the mission of the Church (IMC, Willingen 1952:40). However, there were obstacles to this on the grounds that the work of "foreign" mission was not complete, the theological inappropriateness of independent indigenous churches being completely independent, and the continuing need for money and personnel in the younger churches. In referring to younger churches as free partners in relationship and the results of partnership becoming more manifest, Willingen was reinforcing the conclusions reached at Whitby. Yet, freedom implies the ability to reject relationship however theologically correct the concept might be in terms of pursuing unity. It was also a matter of concern that younger churches suffered the results of the ecclesiological and denominational fragmentation which the older churches imported into their contexts. The concept of solidarity emerges at Willingen, solidarity with the incarnate and crucified Christ and also with the world. It is also conceived as "another kind of solidarity, the tragic frustrating solidarity of a common need" (Willingen Report 1952:33, in Botha 2005:147). This was a crucial matter for the older churches which might be accused of using a theological perspective to maintain dependence. After all, how would they rate themselves as dependent churches regarding their striving for wider and more effective unity? In this, the concept and practice of partnership had achieved nothing. Greater clarity was needed about the meaning of partnership and that was given expression in Ghana six years later.

\subsection{Evanston, WCC, 1954}

This was the second Assembly of the WCC. Representatives from the Third World were far more prominent than at the first assembly in 1948 (Amsterdam) and they took the opportunity to share their visions, talents and gifts in a way that challenged the presumptions of the older churches. They were impatient for change and concerned with the lack of stress on the identity of mission and unity and its negative effect on world evangelisation. However, western attitudes tended to dominate discussions and decisions:

The western world with its needs and preoccupations, is still regarded as the world which really matters. The rest provides a colourful geographical fringe. We have hardly begun to understand what it means to belong to a Church which is worldwide. We tend to think and plan and work within our narrow cultural boundaries. The work of the Church beyond these familiar frontiers is, for many Christians, an exotic growth, an interesting but alien affair.

(Ransom 1954:1133) 


\subsection{Achimota, IMC, 1958}

This meeting took place in Africa and was a testimony to growing independence both in an ecclesiastical and political sense. Several new realities had to be acknowledged. First, new independent states had been established which created new political and cultural scenario. This was accompanied by a great sensitivity arising out of developing self-identities and the demand for equal rights. Concurrently on the ecclesiastical scene there was a similar development among the locally initiated churches of Africa and Asia. Third, the ecumenical movement was beginning to yield fruit. All of this expressed the freedom of the younger churches from the domination of the older churches and from western colonialism and had serious implications for mission societies and limited their scope for and their monopoly over mission. This was not an easy conference for there emerged serious differences concerning the meaning of partnership. This is not surprising in the face of the older churches loss of power and influence. This was the new fact and, indeed, requirement of mission. There could be no concept of "realised" partnership while certain questions remained: "Can the younger church accept the older church with all its pride, its shortcomings, its heritage, its guilt by association? Can the older church accept the younger church in spite of its smallness, its weakness, its spirit of independence? By 'accept' conformity is not implied, but mutual respect for selfhood." (Matthews, in Bauerochse 2001:49.)

Here we come face to face with the issue of vested interests in sending churches which was contradicted by the new concept of the missio Dei which stated clearly that mission was participation in the mission of God and was "a mission that calls for the transformation of all human relationships and the establishment of justice" (Brown 1997:214) and this necessarily meant the transformation of missionary relationships too. This was a difficult meeting marked by conflicts but little resolution, but one thing was clear: "mission in partnership means the end of every form of guardianship of one church over another" (Bosch 1991:370).

\subsection{New Delhi, WCC, 1961}

The Achimota conference had taken place in the context of preparations for the integration of the IMC (fellowship of missionary societies) and the WCC (global fellowship of Churches) thus expressing the essential nature of the church as mission. The IMC became the Commission on World Mission and Evangelism (CWME) of the WCC at its third assembly in New Delhi in 1961. This was a structural and theological attempt to express the truth that mission and unity are inseparable. It meant that the world's main instrument of ecumenism also had responsibility for the missionary task. A Joint Action for 
Mission programme was instituted which aimed to survey needs and opportunities in each area and rationalise resources accordingly. This would be no easy process for it would require considerable commitment and responsibility to repent of past errors and reconcile for future action together through consultation. The old era had passed where: "... the European enters the scene as what the Bible would call "a rich man": somebody who is really somebody and who thinks he can prove it; draped around him he displays his impressive possessions (culture, techniques, spending power). He has everything - except a contrite heart" (Hoekendijk 1964:179).

Yet, "fully committed fellowship" was the sign of the common bond between unity, witness and service. This was the "ecumenical form of partnership idea" (Bauerochse 2001:53) and it took a distinctly social justice form.

\subsection{Mexico City, CWME, 1963}

This was the second meeting of the Commission (CWME) after its formation. It met in a less combative spirit. This was due to the general acceptance of the theological basis for mission in the missio Dei concept. It was also the result of the majority of delegates, once more, emanating from the West. The new focus was on giving practical effect to integration of mission and church in a holistic manner. Mission was the responsibility of all churches throughout the world, not just those in the North: "We affirm that all Christians are called to go forward in this task together. We believe that the time has now come when we must move onwards to common planning and joint action. The fact that Christ is not divided must be made unmistakably plain in the very structure of missionary work (Mexico City, 1963c, in Bosch sa:8).

Hence the theme "Mission in six continents", by which the younger churches challenged the distinction between them and older churches and the presumed existence of borders in mission. Bosch (1980:189) summarized the emphases defined: "It makes the church conscious of her missionary calling in her own environment; it stresses the global extent of the missionary dimension; it helps to combat antiquated paternalistic structures; it questions the traditional one-way traffic in mission as well as Western pride of possession; it makes room for reciprocity."

The adopted slogan was "the whole Church bringing the whole gospel to the whole world" (Neill 1976:50). The methodological approach adopted was for all parties concerned to consider needs, opportunities and resources in each region, consult together with regard to allocation of resources, and then enact their agreements. This approach allowed for greater flexibility and contextualisation. This new focus helped to challenge out of date paternalistic mission structures; it questioned the traditional one-way approach to mission with its Western possessiveness; and it opened the way for a more reciprocal approach to mission. This was necessary for paganism was still paganism 
whether it was found in the West or in the Third World. A major obstacle to progress continued to be the low level of trust and integrity which existed between all the partners and the possessiveness of the donor agencies in terms of finance and information. The challenge was to demonstrate solidarity of responsibility for mission.

\subsection{Uppsala, WCC, 1968}

The missio Dei concept here, took on a new form of partnership: "Partnership in God's mission is therefore entering into partnership with God in history, because our knowledge of God compels us to affirm that God is working out his purpose in the midst of the world and its historical purposes" (Uppsala Report, "The Church for others" 1968:14, in Bosch 1975:96).

Here, it was noted that the worldwide disunity of churches hindered and militated against the church's missionary advance. Questions were raised concerning how the church could be an instrument for unity in the world when she was so divided herself, despite some promising experiments which had been encouraged at the New Mexico meeting of the CWME in 1963? Under the heading of the Uppsala Report "Never go it alone", a call was made to implement the decisions of Mexico 1963 in this regard: "We urge consultation with regional and national councils, mission boards and societies and churches, resolved to find ways and means for such joint planning and action" (McGavran [ed] 1972:249-258). "The churches need a new openness to the world in its aspirations, its achievements, its restlessness and its despair" (Uppsala Report, "The Holy Spirit and the Catholicity of the Church", in Slack 1968:74). The final report emphasized the benefits of change brought about through forgiveness:

... [t]his change is always embodied in some actual change of attitude and relationship. For there is no turning to God which does not at the same time bring man face to face with his fellow men in a new way. The new life frees men for community, enabling them to break through racial, national, religious and other barriers that frustrate the unity of mankind.

(Slack 1968:76)

A pertinent question might be who is going to forgive who in this context?

\subsection{Bangkok, CWME, 1972}

The issue of the relationship between mission and unity was confirmed at Bangkok (1972) where the poorer churches' anger and resentment was clearly expressed: "Now Bangkok 1972 celebrated partnership in mission as 
the new paradigm. But Bangkok also meant a 'farewell to innocence' about the dynamics of power in mission" (Van Hollander 2004:8).

It was saying "in no uncertain terms that the European model of Christianity, was dead, and with it all Western claims to cultural dominance in the two-thirds world" (Scherer 1987:123). This was clearly expressed in Section III of its "Letter to the Churches" on patterns of partner relations: "It is very clear that we must find ways of responding together to our common calling to mission in the six continents of one divided world, so that everyone may take full responsibility and obtain full identity" (in Bosch sa:73). It was aware of the destructive effects of power abuse in terms of church relations as a hindrance to the development of "a mature relationship between churches" founded on "mutual commitment to participate in Christ's mission in the world" (Scherer 1987:123-4). The redressing of unequal relations was dependent on poorer churches moving to a place of lessening dependency while retaining their integrity and identity. The resources were held in the countries of the North which held and exercised control over the countries of the South (Third World). This was problematic but worse, the powerful sending churches conceived mission as a distant project forgetting that they had missionary commitments on their own doorsteps. Often this was due to the situation where mission agencies at home and abroad were separate entities which had little or no contact with one another as in the Church of Scotland departments of National Mission and Overseas Council. So long as this situation endured:

both "partners" know who holds the purse strings and sets the agenda in the south. Meanwhile churches in the north remain unhealthily focused on "mission faraway" and ignore the pressing missiological challenges at home. Unequal relations between north and south result in distorted mission identities in both north and south.

(Van Hollander 2004:8-9)

Issues of social justice continued to predominate and these were linked to partnership through mission which was involved with economic justice, human dignity and personal hope. These were relational matters and to ignore them was to deny salvation as fullness of life. Issues such as these would lead to conflict with evangelical groups in the future. As far as the donor mentality supported exploitative economic systems, it was challenged and moves towards ethical investment to assist the liberation of the poor and oppressed were promoted. The concept of partnership was challenged as empty of 
content and action as younger churches were subjected to power politics through continued dependence. This kind of thinking which led to the development of new international structural models produced two responses, the call for moratorium and CEVAA (Communaute Evangelique d'Action Apostolique: Evangelical Community for Apostolic Action). But, at this point the moratorium debate erupted.

\subsubsection{Moratorium}

The reduction in our grant was based on our own economic situation and priorities. It was made unilaterally. We had not engaged the leadership of this school in dialogue about long-range plans for self-reliance. When we were economically strong we unilaterally contributed large sums of money for capital development and operations. Now that we are in financial difficulties we withdraw in an equally unilateral way. Most Western agencies act in the same unilateral manner; the piper calls the tune. ... This matter of unilateral reductions by donors is a highly sensitive issue. The receiving church rarely has any option but to absorb the blow and suffer the consequences. The damage it is doing to relationships cannot be overstated.

(Hopkins 1977:78)

It was situation such as this that brought a new perspective to interchurch relations. In 1971, Rev John Gatu, General Secretary of the Presbyterian Church of East Africa, proposed the model of moratorium as one approach to redressing then imbalance which would necessitate a period of reflection on mission with the aim of transforming the unidirectional flow of resources to a multidirectional exchange where control and power would be internationalized:

Moratorium was discussed as a means of breaking unequal power relationships between mission boards and local churches; of providing space for local churches to reflect on their self-identity, their calling to mission, their need to develop their own, authentic response to the gospel in their particular patterns of dependency; at the same time a moratorium on the sending of funds and people would give the sending boards extra resources to put into the education of the members of their churches in mission, and to channel into ecumenical mission activities.

(Brown 1997:218-219) 
This became a major issue when, in 1974, the churches which constituted the All Africa Conference of Churches made a similar plea for moratorium. This would be moratorium for mission with the aim of "remaining a respected part of the one Catholic Church." (AACC Lusaka, 8-21 May 1974, in Bosch $1991: 325)$. The Philippine theologian, Emerito Nacpil reached the same conclusion based on the premise that in existing conditions any partnership could only exist between weaker and stronger partners; that is, a partnership of dependence and domination. Therefore, Nacpil concluded, the finest sacrifice the missionary could make was to withdraw and allow other forms of mission to materialise.

Gatu gave expression to younger churches dissatisfaction with the state of partner relations and took strong issue with Stephen Neill by challenging the western view of partnership which resulted in:

we must say to the white advocates speaking for the Africans: I believe that I can speak for myself and I believe I know my own needs, which of course must not necessarily correspond to those that you consider to be the right ones. ... the churches continue to live as appendices of the Western churches and remain dependent.

(in Bauerochse 2001:65)

For western Christians, mission was still a one-way movement. Gatu described it as the "Vasco da Gama mentality of those who set off to explore the world and to help the heathens and the poor" (in Bauerochse 2001:65). Unity and community seemed a far cry from the state of contemporary relationships, especially where money played a vital role in the relationships.

Bangkok took up the issue with a view to developing new forms of relationships and that churches which wished to should go ahead and declare moratoria, work within their own limited means and thus develop their own independence and identity. This would also allow the older churches a period for reflection on their missionary methods and motives. However, it did not receive general support although it did inspire some innovative discussions and moves. Emilio Castro, new head of the Department of World Mission and Evangelism, summed up the debate: "Never should it [a moratorium] constitute the abandonment of our missionary mandate. ... It must be a moratorium for mission, never a moratorium of mission" (1973:140). However, this implied that the older churches trusted their younger partners to act with integrity and challenged themselves to do the same for the sake of the missio Dei. 
In 1974, the Lausanne Covenant, ${ }^{1}$ expressing an evangelical standpoint, expressed the hope that "a growing partnership of churches will develop and the universal character of Christ's church will be more clearly exhibited" (1974, Article 11 in Sogard 1996:199). Yet, it allowed for the possibility of moratorium: "the reduction of foreign missionaries and money in an evangelized country may sometimes be necessary to facilitate the national church's growth and self-reliance and to release resources for unevangelised areas" (Article no 9 in ME 6.6.38, WCC 2005:26). However, according to Bishop Festo Kivengere of Uganda, it became clear that this matter had never actually been raised at grass roots level and what were discussed were largely the views of a limited number of church leaders (Neill 1976:45). But this might be said of most of the deliberations in such situations.

Concurrent with these discussions, the entire issue of world development was assuming centre stage both in the secular realm and in the churches. This was exemplified in the Commission on the Churches" Participation in Development (CCPD). A strategy paper prepared in 1973, focused on the main role players in development: "CCPD conceives development as a process by which people participate in their own liberation. In this way, development is the action people themselves take to change their situation, rather than the result of an increase of the goods and services available to them" (in Bauerochse 2001:68).

This kind of thinking was threatening to the Western world in its search for increasing wealth. Philip Potter (in Bauerochse 2001:69), General Secretary of the WCC, encapsulated the problem tersely: "What we face here is an evangelical and pastoral problem (...): how can we speak through the document to the ordinary member of the church in Western countries, especially at a time when people in the West feel very insecure?" While one response was to identify with the poor of the world in their quest for social justice and liberation, the predominant response was to consolidate vested interests and prevent these things from happening. This was both an ecclesiastical and secular response.

\subsubsection{CEVAA (Communaute Evangelique d'Action Apostolique)}

In some ways CEVAA provided a possible alternative to moratorium. It attempted to model its interchurch relationships on the principle of the communion of goods as in the earliest Jerusalem church (Acts 2:42ff; 4:32ff) It was formed in 1971 having arisen out of reflection on the structures of the Paris Evangelical Missionary Society, and was largely promoted by African

\footnotetext{
${ }^{1}$ emanating from the International Congress for World Evangelisation, Lausanne, Switzerland, July 1974.
} 
members of the network: "their specificity is the inclusion of the partnership and power-sharing principles into the structures of international church communities" (Matthey 1999:106) and represent an attempt to implement the recommendations of the successive missionary conferences which aimed to create structures that facilitated rather than hindered relations between younger and older churches; and it prefigured the WCC Ecumenical Sharing of Resources programme. CEVAA's concept of partnership was akin to that of koinonia. Its particular focus was on co-operation in evangelism and it contributed to the complete integration of church and mission. A novel departure was the approach adopted which allowed all the younger churches to talk directly to one another rather than "via the centre in Europe" (Funkschmidt 2002:399) where the relationship was crudely described as resembling "a rape more than a courtship" (Funkschmidt 2002:568). This situation which has endured involved mission agencies in the West communing regularly to discuss the needs of their common partners and the allocation of resources. While this might have some beneficial effects, it also confirms the exclusive nature of the sending agencies' approach to mission. While they were talking amongst themselves, their partners were mere applicants for grants and assistance, mere subjects of distant beneficence. So policies to ensure equitable sharing of money and power were built into the system. This provided one motivation for the adoption of the block grant system in order that churches should be free to use funds allocated as they wished as "grown-up churches" (Funkschmidt 2002:401). Attempts to replace this system with project related funding led to charges of paternalism.

There was also a serious attempt to recruit missionaries on a wider basis between all member churches in response to Mexico City's "Mission in Six Continents" emphasis. The idea was that all member churches should be sending and receiving churches and those exchanges between younger churches should take priority.

\subsubsection{Formation of the Council for World Mission (CWM), 1977} In many ways CWM operates on similar principles to CEVAA (Funkschmidt 2002:396ff). In 1977, the Council for World Mission (successor to the London Missionary Society and the Congregational Council for World Mission) moved from being a mainly British organization to an international mission partnership. A process had begun in Singapore (1975) where, among other things it was recognised that as things were presently constituted "it perpetuates the relationship of donor and recipient and that it fails to give adequate place to the talents of every Church in the co-operative enterprise" (in Evans 1987:458). CWM consists of 31 churches spread throughout six 
regions. The restructuring was a move to break with the donor-recipient model of relating. All its members are committed to the partnership according to its ability to contribute; each receives according to need and stewards the common material and non-material resources for the benefit of the mission to all. In principle, no church has power over another, but each is accountable to all: "All the churches are important parts of the Body of Christ; all are called to and given gifts for mission, which is of the very essence of the church. The powerful are opened to the critique of the powerless" (Brown 1997:221).

This accountability is based on Gal 6:1-5 where partnership requires Christians to be active in critical solidarity as well as critical distance. This is fundamentally important for: "[c]an we speak in credible terms of partnership between the dominant and the dominated, the powerful and the powerless, the large and the small, the rich and the poor, the black and the white, the oppressor and the oppressed? It is a relevant question especially for CWM where indeed many of these polarities exist" (Evans 1987:468). This has produced an innovative equitable approach to mission which is deserving of the name of partnership:

Theologically, the new patterns of relating and holding in common
are anticipatory signs of the eschatological community, where all
live and work in true interdependence. Psychologically, the new
power structure helps the churches to grow out of inherited
identities and develop a more biblical understanding of who they
are as missional churches.

(Van Hollander 2004:9)

Aware of the gospel partisanship in terms of power and its abuse, it was agreed that power would be shared as equitably as possible and that the "concept of partnership, ... implied not only common sharing but also holding as much as was possible in common" (Evans 1987:458). The aim was the empowerment of the traditionally powerless. A radical part of the agreement made was that "we do not cease to use the resources we have for God's purpose, but we cease to regard them as our own" (in Evans 1987:459). This involves a degree of vulnerable stewardship, particularly for the former sending churches who have voluntarily given up much of the control they previously exercised.

It allows for "prophetic integrity and disturbing relevance" (Evans 1987:470). If all of the churches have been endowed with all the resources needed for mission then that means that the younger poorer churches share in this endowment and the ability to witness to their older colleagues. Thirty 
years of experience have proved the worth of this praxis model of mission. Thorne (1987:498) described CWM as a philosophy. This being the case it is an extremely practical philosophy. However, even this new policy approach is not static for it underwent a substantial re-evaluation since 1996 when a property was sold in Hong Kong which provided a very substantial endowment for its work in mission. CWM established a Mission Programme Support Fund (MPSF) from which disbursements are made on the basis of members' discerned priorities. The emphasis has moved from funding development projects "to God's saving work of saving people and saving creation" (Pierce 2003:26).

Ultimately, by discerning the anticipatory signs of the eschatological community new patterns of relating in authentic interdependence developed: "Partnership is costly. It means trying out, opening up, letting go. It is the Easter story all over again. As Robert Latham reminded the CWM board during the 1974 restructuring debate: 'the pattern of death and resurrection is the norm for Christians and for their institutions"' (Van Hollander 2004:10).

Since its reorganisation in 1977, and as the result of subsequent developments, the example of the CWM offers some insights of value for partner church relations. Its Council is inclusive, containing representatives from different regions and includes women and youth members. In this way, and in its manner of operating, CWM has made a decisive shift towards a partnership in mission between and among its members. Each church contributes as it is able and power is shared in the allocation of funds; there is much mutual sharing of gifts and resources. It bases its understanding of the gospel and mission in Acts 1:8 in the work of a community of witnesses. This is holistic and inclusive. Each partner is required to covenant with one another in respect of sharing resources multidirectional, engage in multilateral decision making and participate in common mission activities. The Council is committed to ecumenism as the result of the coalescence in its thinking of mission and unity. It does this by acting as a facilitator. And it is an instrument of mission rather than an active participant itself where resources are pooled. What is lacking is full transparency in its members' activities through mutual theological accountability and prophetic witness. There is often the perception that it is the church alone which is God's partner in mission. However, God has also chosen to identify with the poor and the oppressed so the challenge is for churches to share in the struggles of the marginalised that is to become partners with God's partners in "going beyond ourselves" (CWM 1996:297). CWM conveys a positive self-image, but what of other agencies which have for a long time been involved in mission? 


\subsection{Melbourne (CWME), 1980}

This conference of the Commission on World Mission and Evangelism emphasised that the petition "your Kingdom come", which was its theme, should be prayed in solidarity with the poor of the world. Liberation theology was prominent in the discussions as was the call for solidarity with the poor (cf Lk 4:18-21). Not surprisingly, there was a clear rift between the evangelicals and those who were preoccupied with social justice matters. No allowance was given to those who would play material poverty off against spiritual poverty for in the world; it is the poor who are proclaiming the good news and are active in the amelioration of their peculiar circumstances. The older churches had much to learn from such as these. A German delegate, Gerhard Hoffmann (in Bauerochse 2001:72) commented: "They are no longer the people who need us. They are now (and were really always) people whom we need if we wish to be saved for the kingdom of God: as Christ is with them, we can only have him if we are also with them."

For as logical as this thinking was, it was also extremely radical for those who had not heard the message presented in this manner before, especially in the dramatically new approach to relationships. Dependence had shifted place towards being a description the older churches' role. This posited several consequences for them. First, they had to take more seriously their responsibility for inaugurating the responsible community of the people of God. Then, they had to set clear priorities in the use of money. Third, they had to engage with political and economic struggles in order to alter existing balances of power in favour of the poor. Philip Potter (in Bauerochse 2001:73), WCC General Secretary, accurately summarised the situation which had not, nor would change in the immediate future: “... we have not got very far in the ecumenical sharing of resources and in our partnership in the gospel. The power of money and of other resources has prevailed". A letter sent to the churches states: "Our world is deeply wounded by the oppressions inflicted by the powerful upon the powerless. These oppressions are found in our economic, political, racial, sexual and religious life" (IRM 1980:253). Power is a neutral commodity until it is exercised. It is also a fundamental component of any relationship including sharing partnerships. What is vital, however, is that power: "should be faced openly and its implications confronted. The worst form of power is not so much that of naked aggression or the flaunting of authority but the disguised and manipulative schemings whose aim is control of opinion and decision-making. I suppose the slogan would have to be, 'In all things, transparency'” (Kirk 1999:198).

A positive aspect of Melbourne was that it was composed of delegates from churches and no longer from mission societies; integration had 
proceeded apace. Despite a virtual moratorium on talk about partnership, "mutual witness" in a two way flow was emphasised that focussed on the use of power: "to build interchurch relations without challenging our own power structures which dehumanise and betray the kingdom, is to build on sand.... We need to be converted ... towards an action that reflects the crucified Christ in the way we use power in mutual relationships" (WCC 1980, par 25)

A major concern which went beyond the functional quality of partnership, was the unity of churches in mission through missionary action and Eucharistic celebration. This community was described in terms of koinonia. This raised not only issues of the balance between quietism and social action, and the need for celebration through the search for justice in church and world:

\begin{abstract}
Where a people is being harshly oppressed, the eucharist speaks of the exodus or deliverance from bondage.

Where Christians are rejected or imprisoned for their faith, the bread and wine become the life of the Lord who was rejected by men but has become the "chief cornerstone".

Where the church sees a diminishing membership and depressed budgets, the eucharist declares that there are no limits to God's giving and no end to hope in him.

Where discrimination by race, sex or class is a danger for the community, the eucharist enables people of all sorts to partake of the one food and to be made one people.

Where people are affluent and at ease with life, the eucharist says, "As Christ shares his life, share what you have with the hungry.
\end{abstract}

(Bauerochse 2001:74)

However, little of positive worth emerged in the subsequent practice of the churches. Yet, this does not minimise their relevance for the form that partnership takes. Sadly, the gap which separated rich from poor continued to widen. By the end of the 1970s, the term partnership came to refer to any form that inter-church relations, aid and activity took. The 1980s were to be occupied with discussions concerning the ecumenical sharing of resources.

\title{
3. THE ECUMENICAL SHARING OF RESOURCES
}

The initiative for the study process on the ecumenical sharing of resources had its inception at the 1975 Nairobi assembly of the WCC. And this issue had its source in the moratorium debate. The credibility of Christian witness was at stake here. Several meetings took place at regional and national levels. Two main points emerged as the result of this process. First, the resources being 
referred to were not just material but also included spiritual, religious and cultural values. Second, there was a clear negative critique of the dominator model reinforced by unequal power relations. There needed to be a move on the part of the poor themselves to rectify these power inequalities. That is, the poor needed a stimulus to act as a periodic attractor to challenge the wealthy and powerful of the church and world. They must become participatory communities that are communities of partnership: "To do this requires practical solidarity in dependence and interdependence on each other" (Bauerochse 2001:78). This basis was outlined at Melbourne in the concept of the church as a sharing community grounded in Eucharistic celebration and it requires mutual transparency and accountability. A new model was proposed, that of churches of equal standing sharing with one another e. g. two younger churches.

\section{I El Escorial, 1987}

These proposals were given concrete expression at El Escorial in Spain in October 1987. They were formulated as "guidelines for sharing". Spiritual goods came to be considered of greater value than material resources, that is "Information, communal traditions, wisdom, organisations and a technology of survival" (in Bauerochse 2001:79). The practical implications of sharing were given more concrete expression than ever before in a number of guidelines:

\footnotetext{
- $\quad$ the involvement of the marginalised in decision making as equal partners.

identification with the poor and oppressed and their organised movements in the struggle for justice.

bearing witness to the mission of God by confronting the structures of injustice.

enabling people to organise themselves and realise their potential and power.

opening to one another as friends in mutual trust and accountability.

sharing with one another our needs and problems in relationships where there are no absolute donors or absolute recipients.

promoting the holistic mission of the church in obedience to God's liberating will.

the sharing of resources among churches of the south.
}

(Brown 1997:223)

In both the short term and long term these guidelines were not taken seriously and acted upon. There was a lack of commitment to change on the part of the 
older churches and the guidelines were not formulated in a user friendly manner with too much emphasis on "a globalisation exaggerated to the extreme" (Bauerochse 2001:80). One positive result of the process arose out of advice tendered by Konrad Raiser to the El Escorial meeting which strengthened the ecumenical vision of the church as a sharing community which would not simply accept the existing ecclesiastical power structures.

\section{MISSION AND EVANGELISM: AN ECUMENICAL AFFIRMATION (ME), 1982}

ME was the result of preparatory work carried out by the CWME which culminated in a document which represented the official policy of the member churches of the WCC. It met the aspirations of both the "ecumenicals" and the "evangelicals". The eucharist remains central to the movement of mission in unity of the church both in agreement and divergence. In its Section ME6.37. "Mission in and to six continents", the document emphasises the necessity of mission beginning at home: "The Christian affirmations on the worldwide missionary responsibility of the church will be credible if they are authenticated by a serious missionary engagement at home" (emphasis in original) (WCC 2005:25).

Moratorium was raised in this context as a means whereby churches have "freedom to reconsider present engagements and to see whether a continuation of what we have been doing for so long is the right style of mission for today" (WCC 2005:26). It reinforced the idea already mooted as early as the Nairobi meeting of the WCC in 1975, that mutuality in mission might best be expressed for a time between churches of the North and churches of the South respectively (ME 6.40, WCC 2005:28). This would introduce a new way of churches working together and provide a more authentic base for mission.

\section{SAN ANTONIO, 1989}

Few new advances were made at the world mission conference held at San Antonio. It continued to consider the universal church as a sharing community founded on the eucharist as koinonia. It focussed largely on global problems without making an in-depth analysis of them and their implications. The same may be said of how it dealt with the many resolutions which had been passed regarding partnership in mission. Joint church ventures were promoted and note was taken of the hindrance to eucharistic hospitality as the result of doctrinal differences. Note was also taken of the dangers of proselytism which were rife. The many deficiencies in interchurch relations in this regard which 
became the subject of a WCC study issued in 1997: "Towards Common Witness" (WCC 2005:53):

... churches in partnership in mission must:

repent of past failures and reflect more self-critically on their ways of relating to one another and their methods of evangelising, in order to overcome anything in their theological or doctrinal expressions or missionary policies and strategies which shows lack of love, understanding and trust of other churches.

This arose out of the situation of little change in North-South partnerships and the need to continually confront existing attitudes towards younger churches.

The conference continued to promote the idea that mission was the essential responsibility of every Christian community. It was of the essence of the church and not an arbitrary option. A major concern was to promote sensitivity in interchurch relations. However, while an aggressive approach has often yielded only negative results, great sensitivity has not been known to produce more positive results in many cases and no significant alteration in the practice of the mission of the older churches was discernable. The expression of partnership came to mean the exoneration of the older churches' responsibility arising from the combination of dependency and disobedience in the younger churches. A novel suggestion was made to the older churches that they engage in transformation "through the transfer of power and funds to a common governing body in which all the partners - in both North and South - can share on a footing of real equality" (Bauerochse 2001:86). It was also suggested that they embark on experiments in mission in putting this, and other, principles into action. In summary it might be agreed with Bauerochse $(2001: 86)$ that:

The term "partnership", which was hardly used anyway, experienced yet again a shift in emphasis. It had been used at the beginning ... to bind the churches of the South into the missionary work (Whitby), and later to justify the continuing right of Western missionary activity in the South in spite of the demand for a moratorium (Bangkok). Now in San Antonio it served to cover up conflicts, which had arisen out of the still existing imbalance of relationships. ... The term "partnership" now suggested a relationship between the churches based on equality and mutual sharing which however did not actually exist.

This constituted a damning indictment of many years of missionary relationships. Theo Ahrens (in Bauerochse $2001: 86$ ) pointed to a possible way 
forward when he suggested that the older churches needed to formulate their expectations of their partner relationships clearly and practically and invite their partners to share in these. While this might indicate an advance in thinking it seems strange that the younger churches were not invited to do the same.

\section{VANCOUVER, WCC, 1983 AND CANBERRA, WCC, 1991}

These two WCC assemblies produced little that was innovative in the field of interchurch relations. Rather they reaffirmed the guidelines for sharing set out at EI Escorial and those in the ME document. While at Vancouver, the critical stance in favour of the poor was adopted, it was another thing when it cane to offering a serious critique of the wealth of the West, both church and world. There was a clear dissonance between accepting the integrity of the poor but not of responding to it appropriately through action. Here was a missed opportunity to set priorities and adopt courses of action which would advance the mission of the church. The call to identify with the poor had been replaced with a move towards becoming their advocates. Little had been heard in recent years of the ability of the poor to articulate for themselves.

The call for humility was voiced at Canberra (1991). A two way giving and sharing could achieve reconciliation and mutual growth in order that "all may fully participate in mission" (in Bauerochse 2001:88). The El Escorial guidelines were again recommended for implementation but there was no real advance in the practice of the older churches.

\section{SALVADOR (CWME), 1996}

Here there was a re-emphasis on partnership in mission and mutual interdependence with a concomitant re-emphasis on missio Dei. There was a double challenge; to the older churches to realise that mission was not simply a matter of overseas engagement; and to the younger churches to realise their potential as authentic churches. The good news is shared by all and is to be shared with all. This is a duty, responsibility and privilege: " ... there is only one gospel, our common foundation for a proclamation and a witness; there is only one mission of God, in which we participate as collaborators ...." (Report of section IV: "One sole Gospel - Diverse expressions" in Klagba 1997:134). The collaborative nature of the exercise demands and is based in solidarity, mutuality, reciprocity and sharing of resources. Autonomy is almost anachronistic in this context. The implications are that a rethinking of mission theology is necessary as well as serious consideration of structural changes. A recommendation was made that: 
[t]he WCC should invite the churches, missionary institutions and local communities to practice a common discipline of mutual cooperation in mission taking into consideration the experience acquired and new models. The fundamental values of this discipline are notably mutual challenge and encouragement, the creation of arenas where self-expression is free and without circumspection and where each is heard, a sharing of one's own resources to encourage an authentic interdependence, the participation in decision-making in respect to others' priorities, the patience and consideration of the dynamic nature of relations, the opening to and ongoing search for a greater solidarity, transparency and mutual responsibility, as well as other ecumenical values affirmed in former documents.

(Report on section IV, in Klagba 1997:135)

As we can see there was nothing essentially new here although the challenge to act was clear, not only on the basis of this recommendation but on those of similar historic pronouncements. However, this was all dependent on giving mutual recognition and accepting the values of cultures encountered as well as giving up a competitive spirit in mission work. Openness would inevitably lead to mutual enrichment. In sum, this seemed as if successive conferences were constantly reiterating what had been decided and said before in the hope that someone was listening and ready and prepared to act.

\section{CONSENSUS ON INTERCHURCH RELATIONSHIPS}

By 1973 (Bangkok), a degree of consensus on relationships between younger and older churches had been reached, in theory at least. These included a recognition that all churches are called to engage in mission; that every church is called to be a partner in the missio Dei; where a local church already exists, there needs to be mutual participation in decision-making; in partnerships, all partners have gifts to offer the relationship; maximum transparency should be the aim; all resources belong to God; mission and unity are inseparable; and mutual enrichment is the result of ecumenical sharing. The degree to which these principles have been implemented varies from place to place.

This consensus developed and in 2000, was given fuller form in "Mission and Evangelism in Unity Today" by the CWME. It emphasised that:

Indigenous peoples are challenging the [western] churches to recognise the richness of their culture and spirituality, which emphasises interconnectedness and reciprocity with the whole 
creation. They are asking the churches to work in real partnership with them, doing mission together as equals, in mutual sharing.

(WCC 2005:78)

\section{THE SELF IMAGE OF THE SENDING CHURCHES}

It is difficult to fully agree with Stephen Neill (1976:19): "that they [older churches] are, almost without exception, penitent churches. They have learned to look at themselves with a critical and appraising eye". If that is so, then why has it been so problematic for them to implement the lofty mission ideals they formulated and proclaimed from 1910? It might be good if they had taken to heart the biblical injunction "Why do you look at the speck of sawdust in your brother's eye, with never a thought for the plank in your own?" (Mt $7: 3)$.

We may, however, agree with Neill (1976:19-20) in some of his areas of concern. For too long, the older churches have demonstrated great indifference to the enormous discrepancies in wealth between their nations and between their churches. There has been a further discrepancy in attitude between those who have demonstrated "patronising superiority" towards those whom they consider to be inferior. Hence, relationships have often been marred by insensitivity and have been responsible for disunity. There have been inexplicable tendencies towards collusion with power when injustice has been uncovered and articulated but not acted against. Patronising attitudes have been demonstrated in the promotion of western ways as the "only possible Christian way" (Neill 1976:20). Indigenous spirituality has therefore been denigrated.

\section{CONCLUSION}

At Edinburgh 1910, the younger churches were regarded as a means to mission. While the aim of partnership in the early conferences of the IMC from Jerusalem, 1928, was to co-opt churches for the work of mission, the relationship was approached from the attitude of churches which were independent in their responsibility and decision-making ability. Mission was the task of churches older and younger, not missions. Jerusalem talked of "partnership" and "co-operation". The Tambaram meeting demonstrated the coalescence of unity and mission in "joint responsibility" and signalled the genesis of mission in reverse which was based in the local church. The active nature of mission was emphasised at Whitby as mission was designated as service, "partnership in obedience" through developing mutual relationships. This arose out of the situation where it was recognised that older churches 


\section{The growth of partnership in mission in global mission history}

could not complete the task alone. This gave an opportunity for partnership in mission with both older and younger churches and other agencies actively involved in pursuing a common vision, task and service. Willingen continued this aspect of collaboration in common pursuit, "mission in unity", of the missio Dei.

The Achimota meeting concentrated at a deeper level on the development of the self-identity of the younger churches. Mission and unity came together at New Delhi as aspects of the one mission of God through solidarity in action. As has been seen, by the time of the Bangkok meeting in 1973 , there had been a significant change in the partner concept. Here, it was used to justify the right of mission societies and sending churches to missionary activity in foreign lands where younger churches were established and active. The issue of moratorium challenged these assumptions, at the heart of which were economic issues. The abuse of power in many relationships was challenged and social justice emerged as a necessity for both the mission and the world. This necessitated, also, new forms of relationships.

The specific emphasis at Melbourne was partnership through solidarity with the poor. This led to a degree of conflict with the evangelicals as the struggle became more political. By this time, integration was progressing well and led to a movement for an ecumenical sharing of resources. These developments in theological thinking were helpful and demonstrated a degree of partnership but they led to conflicts.

Partnership was a much discussed issue, but it was not a practical reality from the perspective of the younger churches whose problems were largely economic, both in terms of their poverty and their dependence on foreign aid, and the use of the same money by donors to dominate and control these churches. Partnership cannot be used to describe the relationships between older and younger churches in a clear and comprehensive way, for often it was a guise to veil conflicts. There had been little actual change in terms of repentance on the part of the older churches and agencies which was demonstrable through changes of courses of action. Hence, the San Antonio conference used the concept of partnership to cover up conflict in the mission domain.

A particular issue that militated against the development of partnership was a disparity in priorities. While the older churches were concerned to develop relationships in a manner they could continue to control, yet with more active participation on the part of the younger churches, these younger churches were more concerned with matters of physical survival in a rapidly changing environment. They were struggling with political issues related to a growing nationalism, the demand for independence and later, the results of 
independence. The strong urge towards the development of new meaningful relationships came from a combination of church leaders and the afficionada of the missionary world, who were deeply committed to expressing a renewed coalescence of mission and unity. They were the ones who had caught a vision of the church and world as it might yet be. They could see the value of working together to forge new relationships. Their theoretical base was impeccable. However, they had to contend with their own churches which travelled more slowly and deliberately, having the concerns of the whole church and not just those of mission to deal with. This led to resistance when, for example, it came to the allocation of funds for mission when there were many needs at home, not least on the home mission front, an area which the younger churches came to see as a vital locus of concern if they were to have anything useful to contribute to world mission. They represented the essentially conservative nature of the church. So resistance emerged from the churches they represented; from those who had not caught their vision or who were promoting a different vision, or who were threatened by the vision of reaching out in such a dynamic manner. They tended to retreat into or remain with the dominator model of operating as it provided greater security and also contributed to the maintenance of the status quo.

Perhaps a fitting and honest conclusion is contained in the 2000 CWME document "Mission and Evangelism in Unity" (WCC 2005:84) in the light of the continued existence of many partnerships which are still determined by structural inequality and a structural division which disadvantages younger churches:

In recent decades the churches have become ever more aware of the necessity to engage in mission together, in cooperation, in mutual accountability: hence mission partnerships have been established, some institutional mission structures transformed, and common projects undertaken. The same period however, has seen an escalation of confessional rivalries and competition in many parts of the world. These realities compel the ecumenical family to re-examine issues of mission in unity, cooperation among the churches, common witness and proselytism, and to work towards more responsible relationships in mission.

\section{Works consulted}

Bate, H N (ed) 1927. Faith and order: Proceedings of the World Conference Lausanne, August 3-21, 1927. London: SCM.

Bauerochse, L 2001. Learning to live together: Interchurch partnerships as ecumenical communities of learning. Geneva: WCC. 
Bosch, D J s a Documents on mission, MSR 101. Pretoria: UNISA.

Bosch, D J 1980. Witness to the world: The Christian mission in theological perspective. London: Marshall, Morgan \& Scott.

Bosch, D J 1991. Transforming mission: Paradigm shifts in the theology of mission. Maryknoll, NY: Orbis.

Botha, N 2005. From Edinburgh to Achimota: The World Mission Conferences as a source of missiological knowledge in the thinking of D J Bosch. Studia Historiae Ecclesiasticae XXXI (2), 129-152.

Brown, J 1997. International relationships in mission: A study project. IRM 86,(342), 207-248.

Castro, E 1973. Bangkok: The new opportunity. IRM 62(246), 136-143.

Council for World Mission 1996. Perceiving frontiers, crossing boundaries: Report of the partnership in mission consultation of the CWM. IRM 85(337), 291-298.

CWME 1980. "Your Kingdom come" - A message from Melbourne 1980. IRM 69(275), 253-254.

Dornakal, Bishop of 1927 . The necessity of Christian unity for the mission enterprise of the church, in Bate, $\mathrm{HN}$ (ed), 491-495.

Evans, M 1987. The Council for World Mission's partnership in mission model: Experiences and insights. IRM 76(304), 458-472.

Foreign Mission Committee. Reports to the General Assembly of the Church of Scotland. Edinburgh: Church of Scotland (1960).

Funkschmidt K M 2002. Partnership between unequals: Mission impossible? International Review of Mission 91(362), 395-413.

Funkschmidt, K M 2002. New models of mission relationship and partnership. International Review of Mission 91(363), 395-413.

Hoekendijk, J C 1964. The church inside out. London: SCM.

Hopkins, P A 1997. What next in mission? Philadelphia, PA: Westminster.

International Missionary Council (IMC) 1939. The world mission of the church: Tambaram, 1938. London: IMC.

International Missionary Council (IMC) 1952. The missionary obligation of the church, Willingen, Gemany. Edinburgh: Edinburgh House.

Kirk, J A 1999. What is mission?: Theological explorations. London: Darton, Longman \& Todd.

Klagba, C 1997. Salvador and relationships in mission. IRM 86(342), 133-137.

Lew, T T 1927. The necessity of Christian unity for the mission enterprise of the church, in Bate, $\mathrm{H} \mathrm{N}$ (ed), 495-499.

McGavran, D A (ed) 1972. Eye of the storm: The great debate in mission. Waco, TX: Word Books.

Matthey, J 1999. International relationships in mission. IRM 88(348/349), 105-108.

Menzel, G \& Muller K 1997. Partnership in mission in Muller, K, Sundermeier, T, Bevans, S P \& Bliese, R H (eds), 339-342. Maryknoll, NY: Orbis.

Muller, K, Sundermeier T, Bevans S B \& Bliese R H (eds) 1997. Dictionary of mission: Theology, history, perspectives. Maryknoll, NY: Orbis.

Neill, S 1976. Salvation tomorrow: The originality of Jesus Christ and the world's religions. London: Lutterworth.

Newbigin, L 1958. One body, one gospel, one world. New York: International Missionary Council. 
Nyomi, S 2006. General Secretary praises Thai Church for ecumenical outreach. WARC Update June, 14.

Pierce, K 2003. A new way of supporting mission. Inside out. CWM 36, 26-27.

Ransom, C W (ed) 1948. Renewal and advance. Edinburgh: Edinburgh House.

Ransom, C 1954. Plenary address, WCC Evanston, Christian Century, 22, 133.

Scherer, J A 1987. Gospel, church and Kingdom: Comparative studies in World mission theology. Minneapolis, MN: Augsburg.

Schoonhaven, E J 1978. Tambaram 1938. IRM 67 (no 267, July), 299-315.

Silcock, H T 1928. Account of the council discussion, The younger and older churches, Jerusalem Meeting Report, Vol 3. Oxford: OUP.

Slack, K 1968. Uppsala Report. London: SCM.

Sogard, V 1996. Missiological education through decentralised partnerships in Woodberry, J D, Van Engen, C \& Elliston, E J (eds), 198-207. Maryknoll, NY: Orbis.

Thorne, J F 1987. Council for World Mission's world partnership. IRM 76(304), 498500.

Van Hollander, J 2004. Unless the grain dies ... The continuing challenge of partnership in mission: Council for World Mission - a global community of churches. WARC Update 14(1), 8-9.

Van Hollander, J 2004. Unless the grain dies ...: The continuing challenge of partnership in mission. WARC Update 14(1), 8-10.

Verkuyl, J 1978. Contemporary missiology: An introduction. Grand Rapids, MI: Eerdmans.

Warren, M 1956. Partnership: The study of an idea. London: SCM.

WCC 1980. Mission perspectives: WCC Report on Melbourne 1980. From Edinburgh to Melbourne. Geneva: WCC.

WCC 2005. You are the light of the World: Statements on mission by the World Council of Churches, 1980-2005. Geneva: WCC.

Wisniewski, K 2006. Partnership fund brings faith groups together. WARC Update June 6-7.

Woodberry, J D, Van Engen C \& Ellinson E J (eds) 1996. Missiological education for for the 21st century: The book, the circle and the sandals. Maryknoll, NY: Orbis. 